\title{
Stormwater runoff quality on an urban highway in South Africa
}

\author{
A Robertson, N Armitage, M H P Zuidgeest
}

Roadway sediment and stormwater runoff were sampled from a $15 \mathrm{~km}$ section of the R300 freeway located in the greater Cape Town area, South Africa. Grab samples were collected over a four-month period in 2016 and analysed for metals, hydrocarbons and nutrients. The metal concentration profiles were similar in sediment and runoff samples. The primary pollutants identified in the highway runoff were aluminium, copper, lead, manganese, nitrogen, phosphorus, zinc, total suspended solids (TSS), and oil and grease. The concentrations of each of these elements, barring lead, exceeded the national effluent water quality guidelines. Large volumes of macro pollutants such as cigarettes, plastic and packaging were also observed. The results of this research indicate that Sustainable Drainage Systems (SuDS) should be used in conjunction with highways, particularly where runoff may influence a sensitive or valuable aquatic ecosystem, as it can be a significant non-point source of pollution.

\section{INTRODUCTION}

Highway drainage presents a high risk of non-point source pollution when compared to other urban land use areas, introducing heavy metals, suspended solids and hydrocarbons to urban waterways (Ellis et al 2012). The composition and volume of contaminants depend on a variety of factors, such as climate, rainfall event intensity and duration, and traffic characteristics (Crabtree et al 2006). Whilst there is a large body of international work describing the impacts and water quality characteristics of highway runoff (Sartor et al 1974; Opher \& Friedler 2010; Barbosa et al 2012), the profile and extent of pollution emanating from South African highways remain largely unknown.

Suspended solids are the most common constituent in highway runoff (Kayhanian $e t$ al 2007). Fine suspended particles $(<200 \mu \mathrm{m})$ transport pollutants such as heavy metals and hydrocarbons, and account for a large portion of the overall pollution potential (Sartor et al 1974; Vaze \& Chiew 2002). Several studies report a strong correlation between total suspended solids and heavy metal concentrations (Shinya et al 2000; Han et al 2006; Desta et al 2007).

Copper, iron, lead and zinc are the most commonly reported heavy metals found in highway runoff waters (Opher \& Friedler 2010). The concentration of lead has decreased worldwide with the introduction of unleaded fuel (Khan et al 2006), and current reported values are approximately $10 \%$ of those reported prior to the 1970s (Opher \& Friedler 2010). Other widely reported metals include cadmium, chromium, magnesium and nickel (Göbel et al 2007).

Organic matter such as oils and greases, volatile organic compounds (VOCs) and polycyclic aromatic hydrocarbons (PAHs) are a common constituent in highway runoff waters. Organic substances originate from vehicle fluids such as oils, fuel, brake fluid, wear and tear of rubber elements and engine emissions (Legret \& Pagotto 1999).

Knowledge of pollutant concentrations in highway runoff is necessary to assess and control the impact of stormwater on the urban natural environment. Stormwater management in South Africa largely focuses on flow quantity management, with little, if any, consideration for environmental consequences (Armitage et al 2013). There are no national or provincial policies addressing pollutant removal from stormwater, leaving stormwater management to be regulated at a local level. The City of Cape Town, where this study was conducted, requires the treatment and attenuation of stormwater from developments within the city, and proposes Sustainable Drainage Systems (SuDS) as a means to achieve this (CSRM 2009).

Internationally, SuDS are recognised as best practice to realise holistic stormwater management (Marsalek \& Chocat 2002). SuDS, also known as Low Impact Design
JOURNAL OF THE SOUTH AFRICAN INSTITUTION OF CIVIL ENGINEERING ISSN 1021-2019 Vol 61 No 2, June 2019, Pages 51-56, Paper 0157

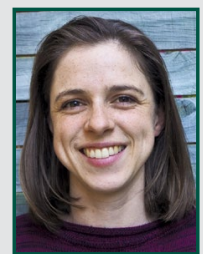

ABBY ROBERTSON works as a design and development engineer at BVi Consulting Engineers. She graduated with an MSc in Civil Engineering from the University of Cape Town in 2017. Her interests are in urban water management, sustainable drainage systems, and using Python to augment engineering design processes.

Contact details:

BVi Consulting Engineers Block B2

Edison Square

corner Edison Way \& Century Avenue

Century City

Cape Town 7441

South Africa

T: +27215277000

E: robertson.abby@gmail.com

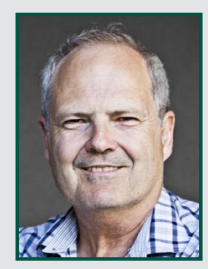

PROF NEIL ARMITAGE Pr Eng, who is a Fellow of SAICE, is Professor in Water Engineering in the Department of Civil Engineering at the University of Cape Town (UCT). His main research interest is urban drainage. He led the team that developed the South African Guidelines for Sustainable Drainage Systems (SuDS), published by the Water Research Commission (WRC) of South Africa (TT 558/13, May 2013). He is Deputy Director of the 'Future Water' Research Institute at UCT.

Contact details:

Department of Civil Engineering

University of Cape Town

Private Bag X3

Rondebosch 7701

South Africa

T: +27216502589

E: neil.armitage@uct.ac.za

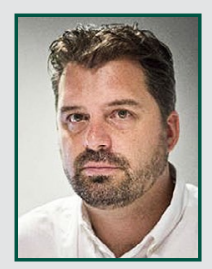

PROF MARK H P ZUIDGEEST is a member of SAICE, and is the SANRAL Chair of Transportation Planning and Engineering at the University of Cape Town. He graduated with an MSc (Civil Engineering) from the University of Twente, The Netherlands, in 1997 , and a PhD from the Netherlands Research School for Transport,

Infrastructure and Logistics (TRAIL) in 2005. His fields of interest include land use - transport systems analysis, with an emphasis on questions around sustainability, equity and accessibility.

Contact details:

Centre for Transport Studies

Department of Civil Engineering

University of Cape Town

Private Bag X3

Rondebosch 7701

South Africa

T: +27216504756

E:mark.zuidgeest@uct.ac.za

Keywords: highway runoff, heavy metals, pollutants, water quality, SUDS 
(LIDs), Water Sensitive Urban Design (WSUD) and Best Management Practices (BMPs), are structural and process controls that attenuate surface flows and improve water quality by means of infiltration, filtration, adsorption, bioaccumulation and percolation inter alia. Examples of SuDS elements include swales (vegetated broad shallow channels), infiltration trenches (excavated pits that are filled with coarse aggregate and often lined with a geotextile) and constructed wetlands (Armitage et al 2013). The stormwater quantity and quality characteristics determine the type, size and number of SuDS elements required to manage stormwater to the desired standard.

The objectives of this study were to identify the primary contaminants in the R300 surface runoff, determine the range of concentrations of the primary contaminants, determine if there is a significant difference between the highway runoff quality and ambient levels of pollution, and to propose an appropriate stormwater management system in the context of the R300 freeway in Cape Town.

\section{METHOD}

The R300, a freeway in Cape Town that links National Roads N1 and N2, was chosen as an appropriate study site (Figure 1). Not only is this highway heavily trafficked - thus likely to demonstrate high stormwater pollutant levels - but it is operated and maintained by the South African National Roads Agency Limited (SANRAL), who funded this study and facilitated data collection.

Sediment and runoff were sampled from three locations on the freeway and one location of undeveloped land adjacent to the R300. The latter sample location was chosen as an environmental control site to distinguish between the ambient levels of contamination and the contaminants present due to road use activities. The sampling sites were distributed along a $15 \mathrm{~km}$ section of the freeway in order to mitigate localised effects. The samples were analysed for heavy metals, hydrocarbons and nutrients at an independent laboratory. Contaminants included aluminium, arsenic, cadmium, chromium, copper, lead, manganese, nickel, zinc, phosphorus, nitrogen, oils and grease, and total suspended solids (TSS). Additionally, various catchpits were monitored before and after rainfall events to identify the macro pollutants transported by

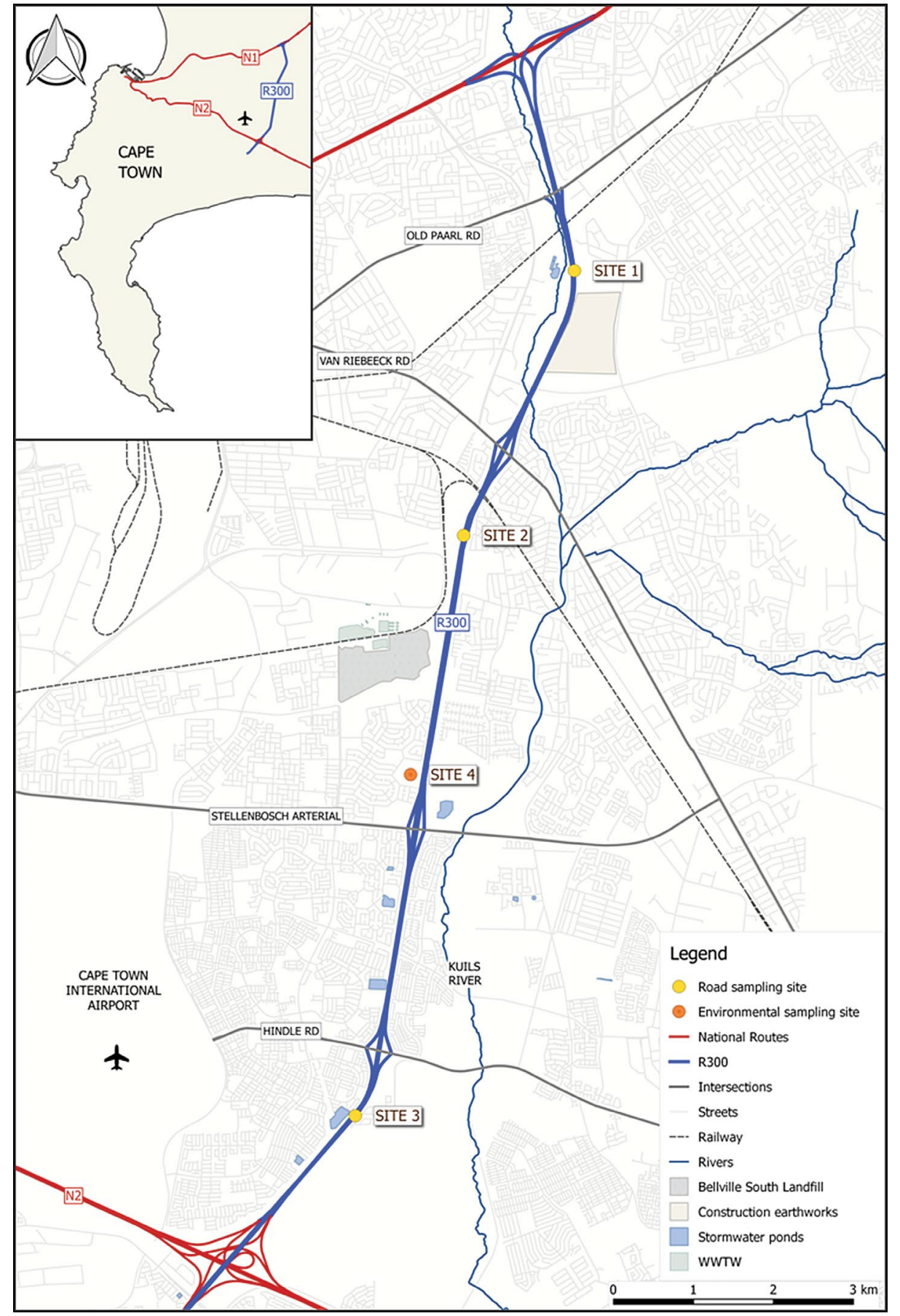

Figure 1 Location map of the R300 and sample positions

stormwater from the road surface to the surrounding environment.

\section{Site description}

The R300 is an asphalt freeway consisting of three lanes in each direction with a speed limit of $120 \mathrm{~km} / \mathrm{h}$. There are mixed land use areas surrounding the road, including low-income formal and informal housing, and commercial and industrial areas. The annual average daily traffic (AADT) is approximately 49500 vehicles/direction/day (SANRAL 2013). Traffic is bimodal on weekdays, with peak volumes from 07:00-08:00 and 16:00-17:00, and the average speed for light vehicles is $93 \mathrm{~km} / \mathrm{h}$ (SANRAL 2013). The highway crosses the Kuils River and lies adjacent to floodplains, wetlands and the Driftsands Nature Reserve. The climate is moderate, with warm, dry summers (December to February) and moderate, wet winters. Annual rainfall ranges between 348 and $707 \mathrm{~mm}$, with a mean annual precipitation (MAP) of $492 \mathrm{~mm}$ based on data obtained from the Cape Town International Airport weather station, which lies approximately $5 \mathrm{~km}$ west of the R300 freeway.

\section{Sample collection}

Grab samples of sediment and runoff from the highway were collected over a fourmonth period from March to June 2016. As an example of typical conditions, Figure 2 shows (a) a highway sample location, 


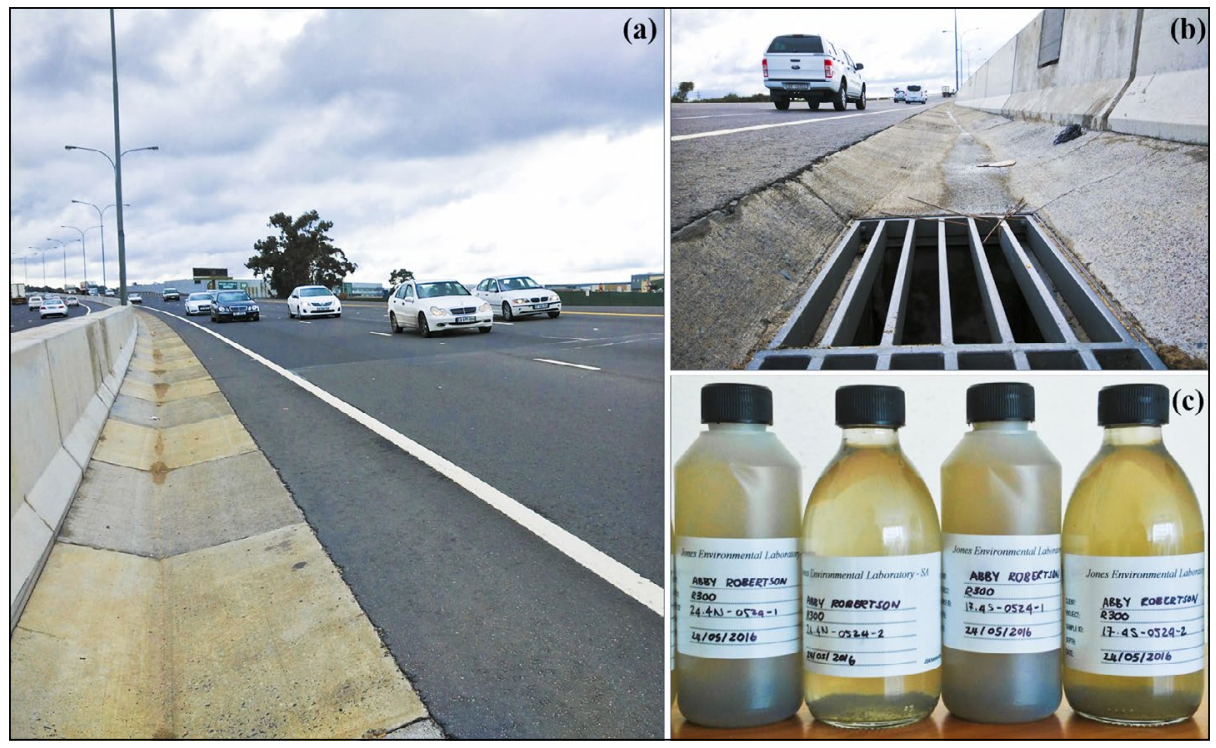

Figure 2 (a) Highway sample location, (b) catchpit inlet, (c) runoff samples

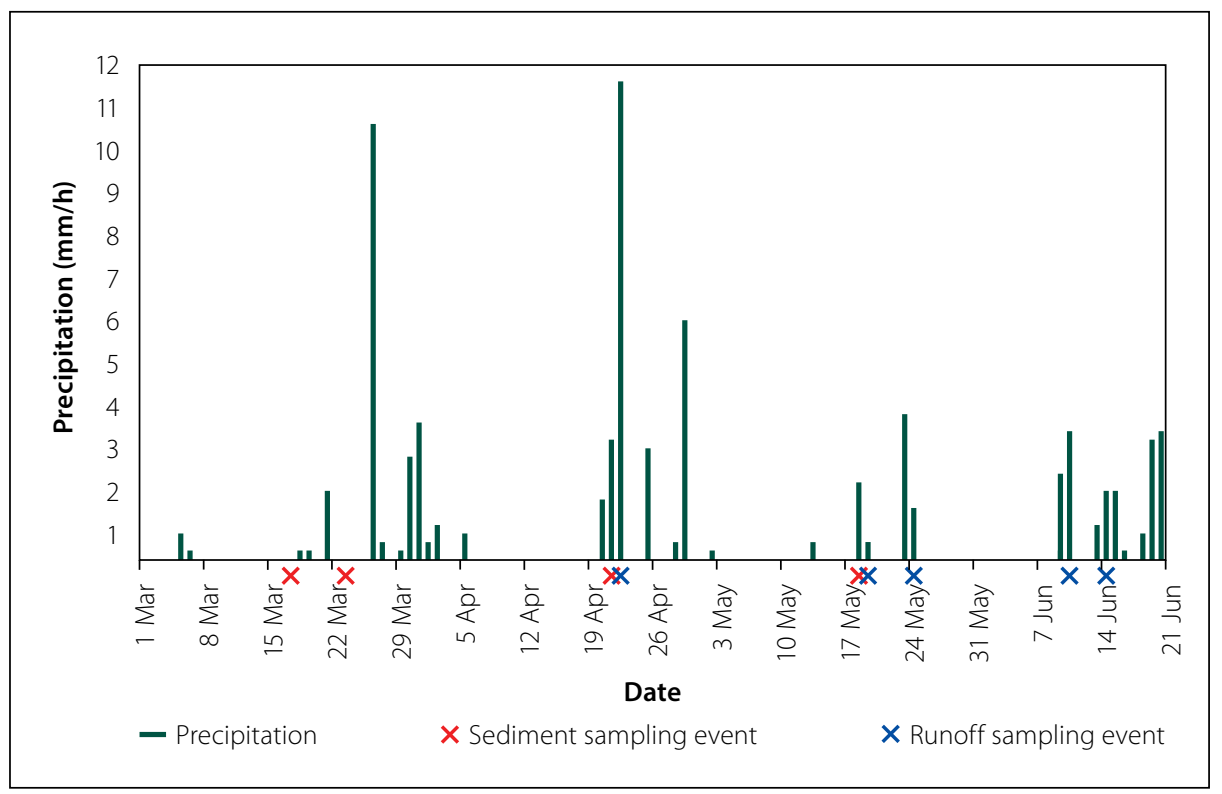

Figure 3 Time series of sampling events and precipitation from March to June 2016

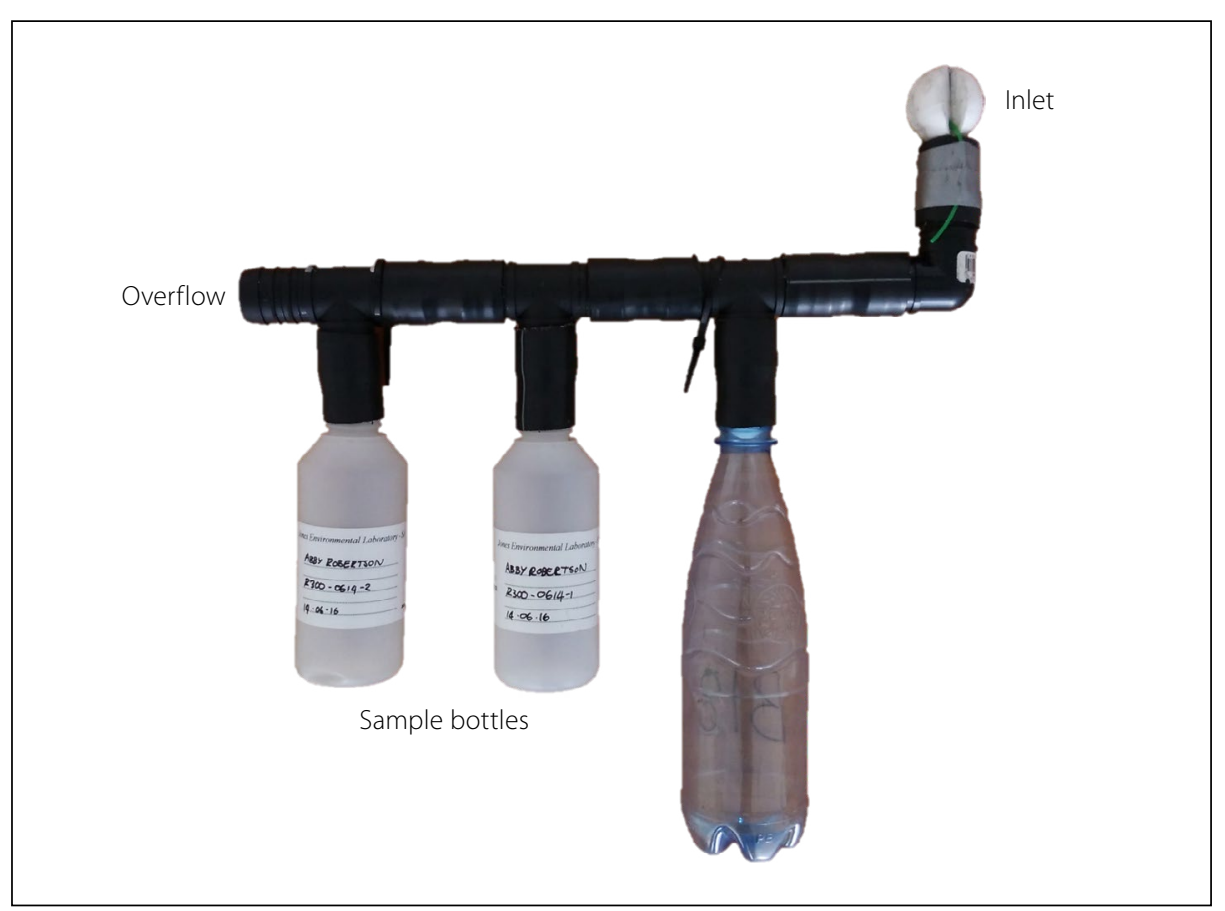

Figure 4 Custom-made sampling device (b) a catchpit inlet, and (c) some of the runoff samples collected. Figure 3 shows a time series of the sample events and precipitation on the R300 during the research period.

Sediment samples were swept with a horsehair brush into a polypropylene dustpan and transferred to amber glass sample jars on site. Care was taken to include the fines fraction in the sample volume as this fraction adheres to the surface of the sampling equipment and has been shown to contain the highest concentration of contaminants (Zafra et al 2011).

Runoff samples were collected using a custom-made sampling device (Figure 4).

The device was designed to sit in the catchpit and capture an extended grab sample of the runoff entering the drain. The device has a flow limiting inlet that samples a small fraction of the incoming runoff, which is channelled to the sample containers through a polypropylene pipe manifold. The extended grab sample collected by this device is a composite sample obtained over a period of 15 minutes to 1 hour, depending on the rate of runoff. The sample containers are sealed by a buoyant stopper once full. Ma et al (2009) showed that this sampling technique reduces the error in estimating mean concentrations by approximately $50 \%$ when compared to instantaneous grab sampling. Research by Deletic (1998) indicates that road surfaces could have a first flush effect, where the runoff is more polluted during the first period of a rainfall event. Therefore, in order to obtain a sample concentration closer to the true mean, the sampling device included a $500 \mathrm{ml}$ storage volume to capture the initial stormwater runoff prior to filling the sample containers. Rainfall was collected in modified PET bottles attached to the top of wooden fence poles, approximately $10 \mathrm{~m}$ from the highway to provide an indication of the baseline pollution levels.

Upon collection, liquid samples were stored in clear glass bottles for oil and grease analysis, and clear plastic containers for metals, nutrients and TSS analysis. Both liquid and sediment samples were subsequently refrigerated and couriered to the laboratory in polystyrene chests with ice packs to preserve the sample.

\section{Analysis}

Sample analysis was conducted according to standard methods at an accredited laboratory (ISO 2005). TSS was determined using the gravimetric method, where the sample is filtered and the resulting residue is dried and weighed. 
COD was tested for by hot digestion with potassium dichromate and measured spectrophotometrically. Oils and greases were determined gravimetrically after petroleum ether extraction. Metal elements were measured by inductively coupled plasma - optical emission spectrometry (ICP-OES). For sediment analysis, samples were dried, ground and digested using aqua regia before ICP-OES.

The particle size distribution of road sediment was determined according to the British Standard 1377-2:1990, Dry Sieving Method (BS 1990). Composite samples were created at each sampling event and manually sieved through nylon and metal sieves ranging from $5.00 \mathrm{~mm}$ down to $0.02 \mathrm{~mm}$.

\section{RESULTS}

Based on visual inspection, the volume of solids accumulated in each catchpit between storm events ranged between 0 and $0.5 \mathrm{~m}^{3}$. Following rainfall events, however, the catchpits were typically scoured clean. The solid waste collected in the catchpits included sand; plant matter such as leaves and grass cuttings; cigarette butts; food packaging such as soda cans; chip packets; sweet wrappers and fast-food containers; and miscellaneous items such as polystyrene, plastic, cardboard and paper.

Table 1 provides the sample mean and range of contaminant concentrations in the sediment and runoff samples. The confidence interval was generated for a $90 \%$ confidence level, calculated using the t-distribution which is suitable for small sample sets $(\mathrm{n}<30)$ (Field 2013). In the absence of water quality guidelines that specify constituent concentrations for stormwater, the results were compared to both the Department of Water and Sanitation's guidelines for preventing toxic effects in aquatic ecosystems (DWS 1996) and the Department of Environmental Affairs' requirements for effluent water quality (DEA 1984). The sample mean concentrations of copper, zinc, phosphorus and nitrogen exceeded both the aquatic ecosystem and effluent water quality standards. The sample mean concentrations of aluminium and lead exceeded the aquatic ecosystem guidelines, while the sample mean concentrations of manganese, oil and grease, COD and TSS exceeded the effluent standards. The concentrations of chromium, arsenic and cadmium were, however, within the permissible limits for maintaining health and biodiversity.

There was no significant spatial variation in the contaminant concentrations between
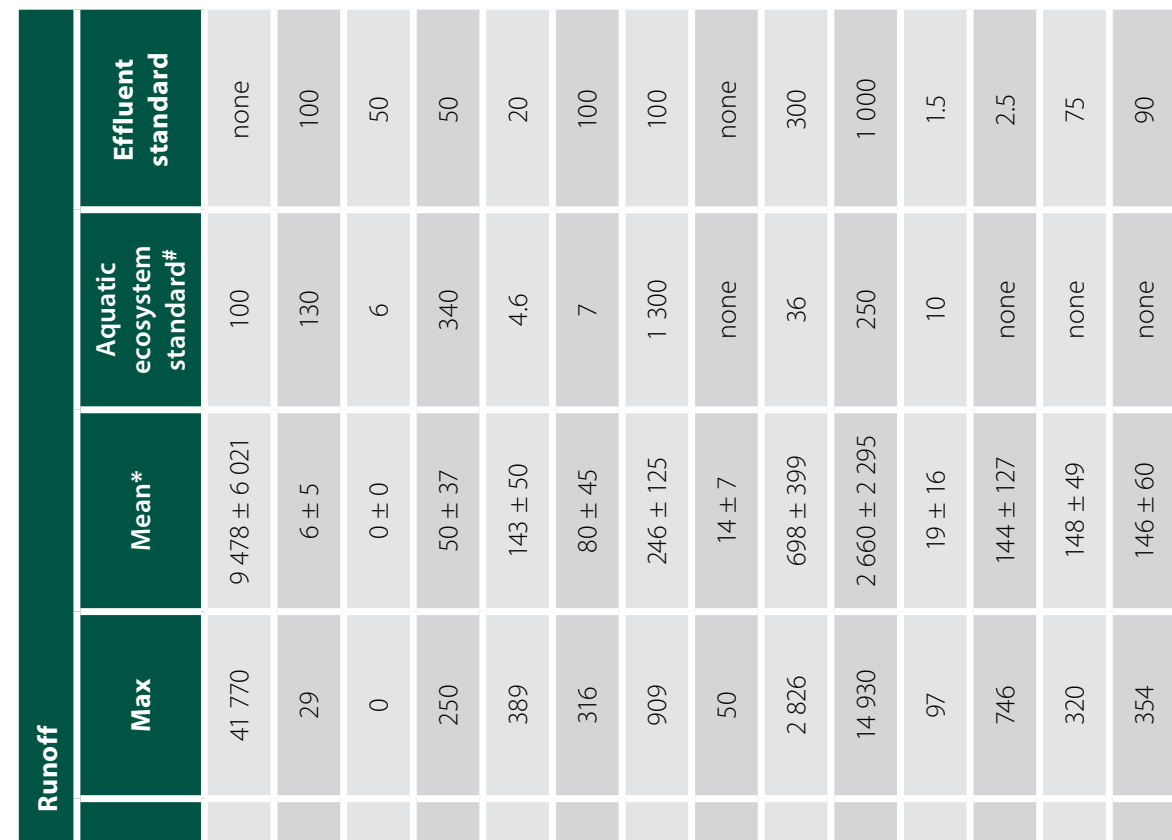

\begin{tabular}{|c|c|c|c|c|c|c|c|c|c|c|c|c|c|}
\hline 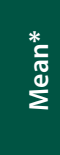 & 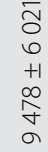 & $\begin{array}{l}n \\
+1 \\
0\end{array}$ & $\begin{array}{l}0 \\
+1 \\
0\end{array}$ & $\begin{array}{l}\hat{m} \\
+1 \\
0 \\
\text { in }\end{array}$ & $\begin{array}{l}\text { คn } \\
+1 \\
\stackrel{m}{ \pm}\end{array}$ & $\begin{array}{l}\text { rq } \\
+1 \\
+1 \\
\infty\end{array}$ & 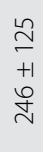 & $\begin{array}{l}x \\
+1 \\
\Xi\end{array}$ & $\begin{array}{l}\text { } \\
\text { mे } \\
+1 \\
\infty \\
o\end{array}$ & 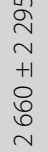 & $\begin{array}{l}\sigma \\
+1 \\
\sigma \\
\sigma\end{array}$ & 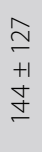 & $\begin{array}{l}\stackrel{g}{+} \\
+1 \\
\infty \\
\stackrel{0}{ \pm}\end{array}$ \\
\hline
\end{tabular}
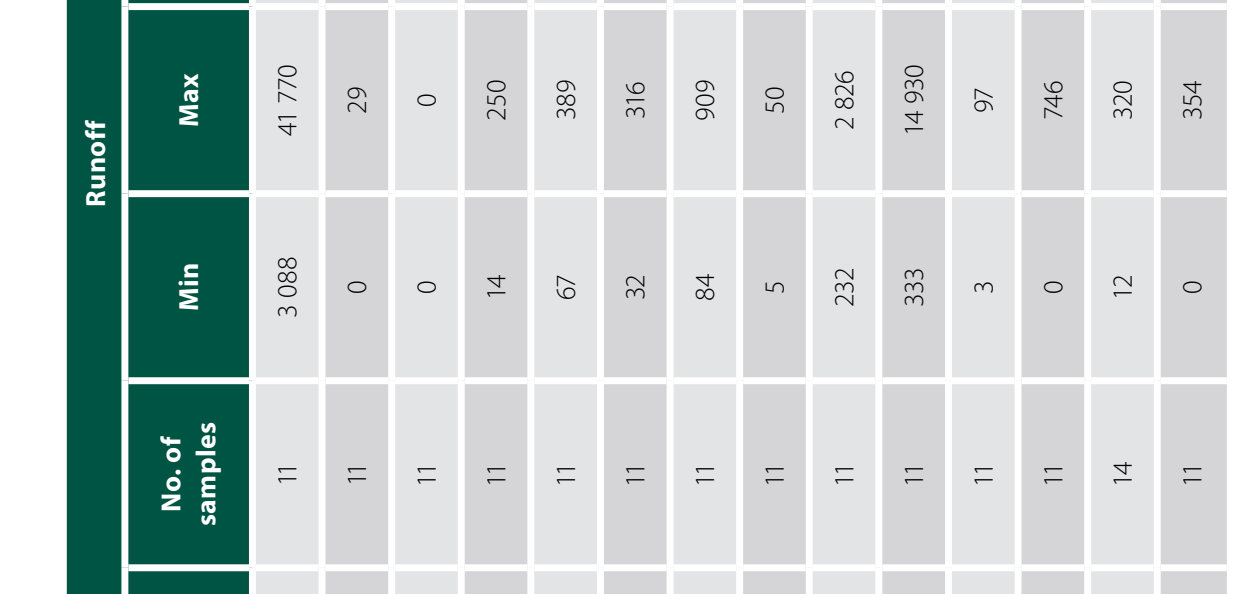

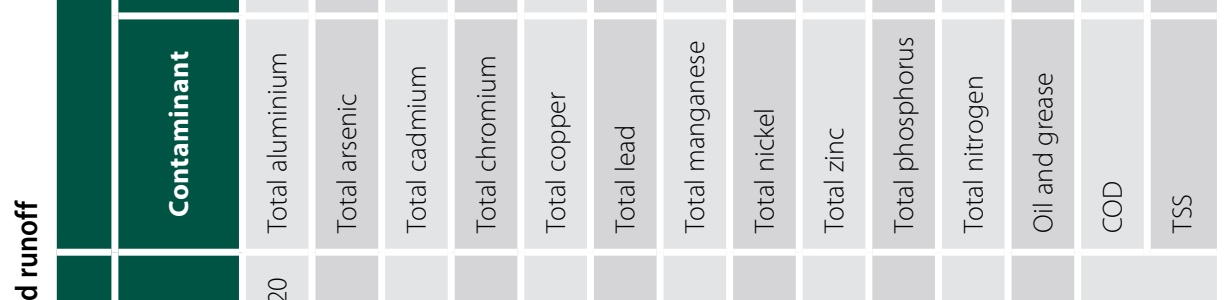

$\left.\frac{5}{\Sigma} \quad \begin{array}{c}\infty \\ \infty \\ m\end{array}\right)$

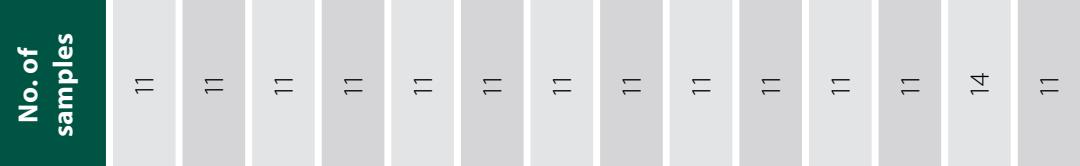

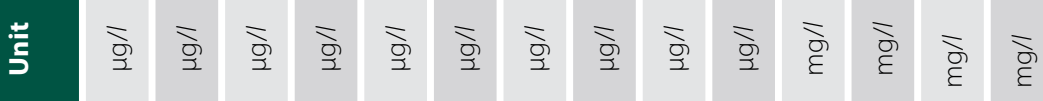

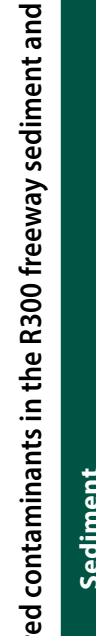

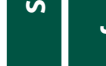

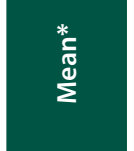

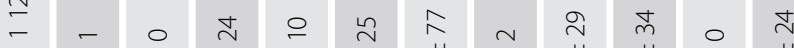

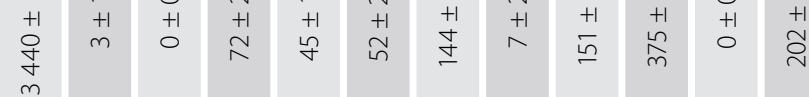

\begin{tabular}{|c|c|c|c|c|c|c|c|c|c|c|c|c|}
\hline 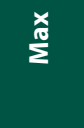 & $\underset{\text { m }}{\stackrel{\infty}{n}}$ & in & 0 & దิ & $\infty$ & б & $\underset{m}{\approx}$ & $\simeq$ & \& & 市 & 0 & $\stackrel{\sim}{\sim}$ \\
\hline$\frac{\mathrm{s}}{\Sigma}$ & $\underset{\sim}{\stackrel{m}{\sim}}$ & - & 0 & $\stackrel{ \pm}{\sim}$ & $\stackrel{ \pm}{\sim}$ & 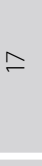 & $\stackrel{\infty}{\emptyset}$ & $\nabla$ & $尺$ & $\underset{\sim}{\bar{\sim}}$ & 0 & $\stackrel{\varrho}{=}$ \\
\hline $\begin{array}{l}\stackrel{y}{0} \\
\dot{0} \\
\dot{0} \\
z\end{array}$ & 6 & 0 & $\simeq$ & $\simeq$ & $\simeq$ & $\simeq$ & $\bullet$ & 0 & $\simeq$ & $\simeq$ & 0 & $\simeq$ \\
\hline 芒 & $\begin{array}{l}\text { शे } \\
\text { के } \\
\text { है }\end{array}$ & $\begin{array}{l}\text { शे } \\
\text { के } \\
\text { है }\end{array}$ & $\begin{array}{l}\text { शे } \\
\text { के } \\
\text { है }\end{array}$ & $\begin{array}{l}\text { शे } \\
\text { के } \\
\text { है }\end{array}$ & $\begin{array}{l}\frac{\text { q }}{\text { के }} \\
\text { है }\end{array}$ & $\begin{array}{l}\text { शे } \\
\text { के } \\
\text { है }\end{array}$ & $\begin{array}{l}\text { शे } \\
\text { के } \\
\text { है }\end{array}$ & $\begin{array}{l}\text { शे } \\
\text { के } \\
\text { है }\end{array}$ & $\begin{array}{l}\text { शे } \\
\text { के }\end{array}$ & $\begin{array}{l}\text { शे } \\
\text { के }\end{array}$ & o & $\begin{array}{l}\text { gे } \\
\text { के }\end{array}$ \\
\hline 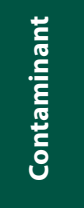 & 歺 & $\begin{array}{l}. \frac{u}{\bar{\nu}} \\
\stackrel{\tilde{\omega}}{<}\end{array}$ & $\begin{array}{l}\frac{\varepsilon}{J} \\
\frac{\vec{g}}{0} \\
\tilde{U}\end{array}$ & 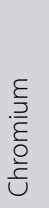 & $\begin{array}{l}\overline{0} \\
\stackrel{0}{0} \\
\stackrel{0}{0}\end{array}$ & $\stackrel{\mathscr{\Xi}}{\Xi}$ & 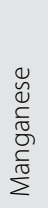 & $\begin{array}{l}\overline{\bar{v}} \\
\frac{\bar{v}}{Z}\end{array}$ & 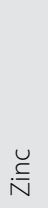 & $\begin{array}{l}\text { בั } \\
0 \\
\frac{0}{0} \\
\frac{0}{0} \\
\frac{0}{\alpha}\end{array}$ & 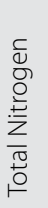 & 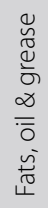 \\
\hline
\end{tabular}


Table $2 \mathrm{t}$-Test parameters for the difference in contaminant concentrations between the R300 road surface and surrounding environment

\begin{tabular}{|c|c|c|c|c|c|c|c|c|c|}
\hline & & & \multicolumn{2}{|c|}{ Road surface } & \multicolumn{2}{|c|}{ Environment } & \multirow[b]{2}{*}{ df } & \multirow[b]{2}{*}{ t-stat } & \multirow[b]{2}{*}{ p-value } \\
\hline & & & mean & SD & mean & SD & & & \\
\hline \multirow{3}{*}{ Sediment } & Heavy metals* & $\mathrm{mg} / \mathrm{kg}$ & 2116 & 2093 & 227 & 231 & 12 & 3.1 & 0.005 \\
\hline & Total phosphorus & $\mathrm{mg} / \mathrm{kg}$ & 375 & 65 & 204 & 19 & 14 & 8.2 & $5.4 \mathrm{E}-07$ \\
\hline & Fats, oil \& grease & $\mathrm{mg} / \mathrm{kg}$ & 202 & 46 & 0 & 0 & 11 & 15.3 & 4.7E-09 \\
\hline \multirow{4}{*}{ Runoff } & Heavy metals* & $\mu g / l$ & 10715 & 12223 & 539 & 447 & 10 & 2.8 & 0.01 \\
\hline & Total phosphorus & $\mu g / l$ & 2660 & 4199 & 46 & 3 & 10 & 2.1 & 0.03 \\
\hline & Oil \& grease & $\mathrm{mg} / /$ & 144 & 233 & 80 & 161 & 10 & 0.5 & 0.3 \\
\hline & TSS & $\mathrm{mg} / \mathrm{l}$ & 146 & 110 & 0 & 0 & 10 & 4.4 & 0.001 \\
\hline
\end{tabular}

the three sample locations on the highway. The data was grouped into 'highway' and 'environmental' categories to determine whether the highway land use contributes significantly to the stormwater quality characteristics. Two-sample t-tests assuming unequal variances were performed to assess whether there is a statistically significant difference between (a) highway and environmental sediment contamination, and (b) highway runoff and rainwater quality characteristics (Table 2). This assessment showed that the sediment collected from the R300 freeway was significantly more contaminated with heavy metals, phosphorus and fats, oils and greases than the surrounding environmental sediment. Similarly, the concentrations of heavy metals, total phosphorus and TSS were significantly greater in the road runoff compared with rainwater from the same location. Based on the sample results, it was not possible to establish whether the oil and grease concentration was different in road runoff and rainwater collected at the environmental sample location.

The metal contaminant concentration profile was similar for both the sediment and runoff on the R300 freeway. Figure 5 shows the distribution of sample mean metal concentrations, indicating the relative concentration of each contaminant. Aluminium, phosphorus, zinc and manganese were present in the highest concentrations, while arsenic and nickel were found in low concentrations, and the concentration of cadmium was below the detectable limit. These results support the notion that sediment analysis provides useful information regarding runoff water quality.

The highway sediment particle size ranged between $0.02 \mathrm{~mm}$ and $5 \mathrm{~mm}$, with an $85^{\text {th }}$ percentile size of $0.83 \mathrm{~mm}$. This compares to other highway sediment studies (Vaze \& Chiew 2002; Anta et al 2007;

Zafra et al 2011). Figure 6 shows the average

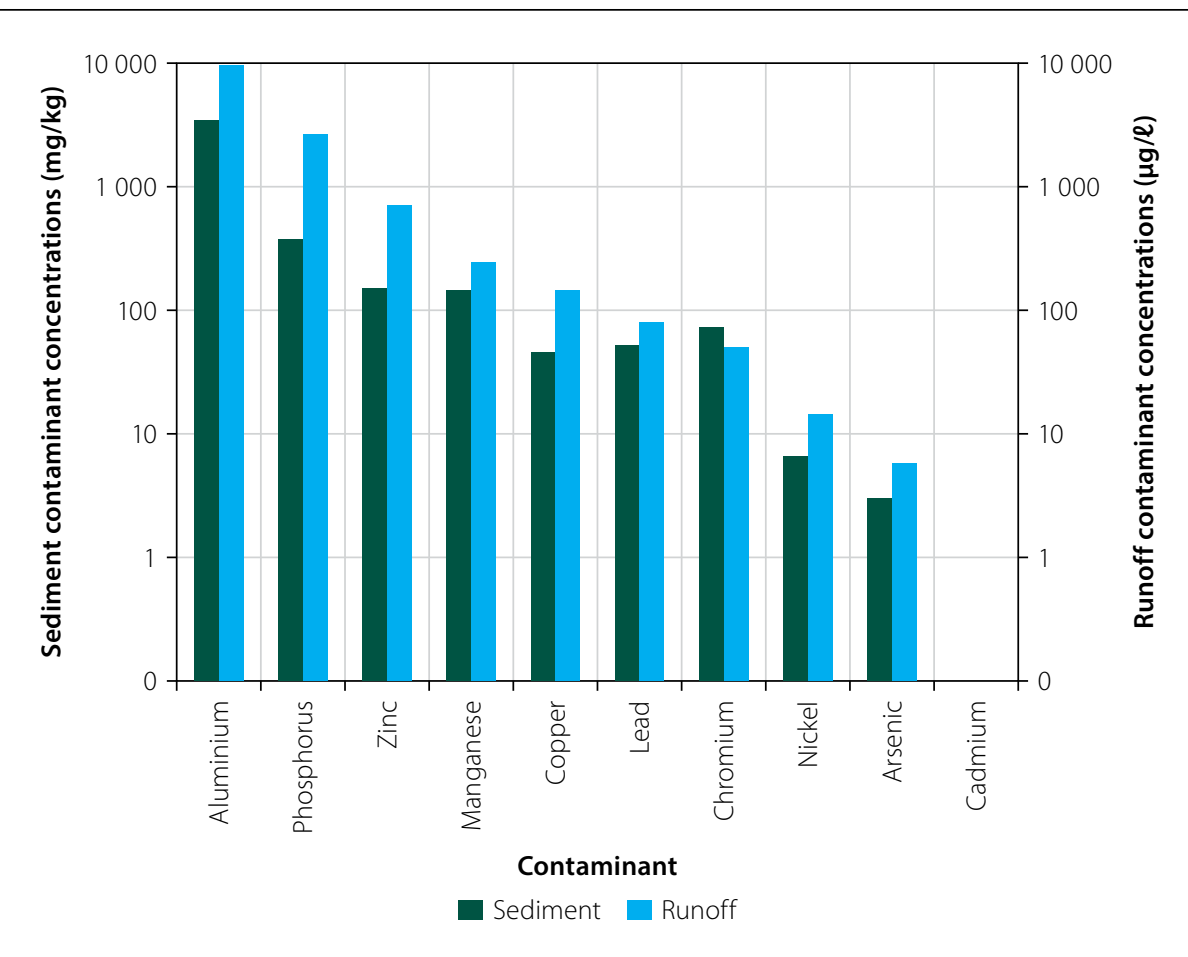

Figure 5 Relative mean metal contaminant concentrations in sediment and runoff

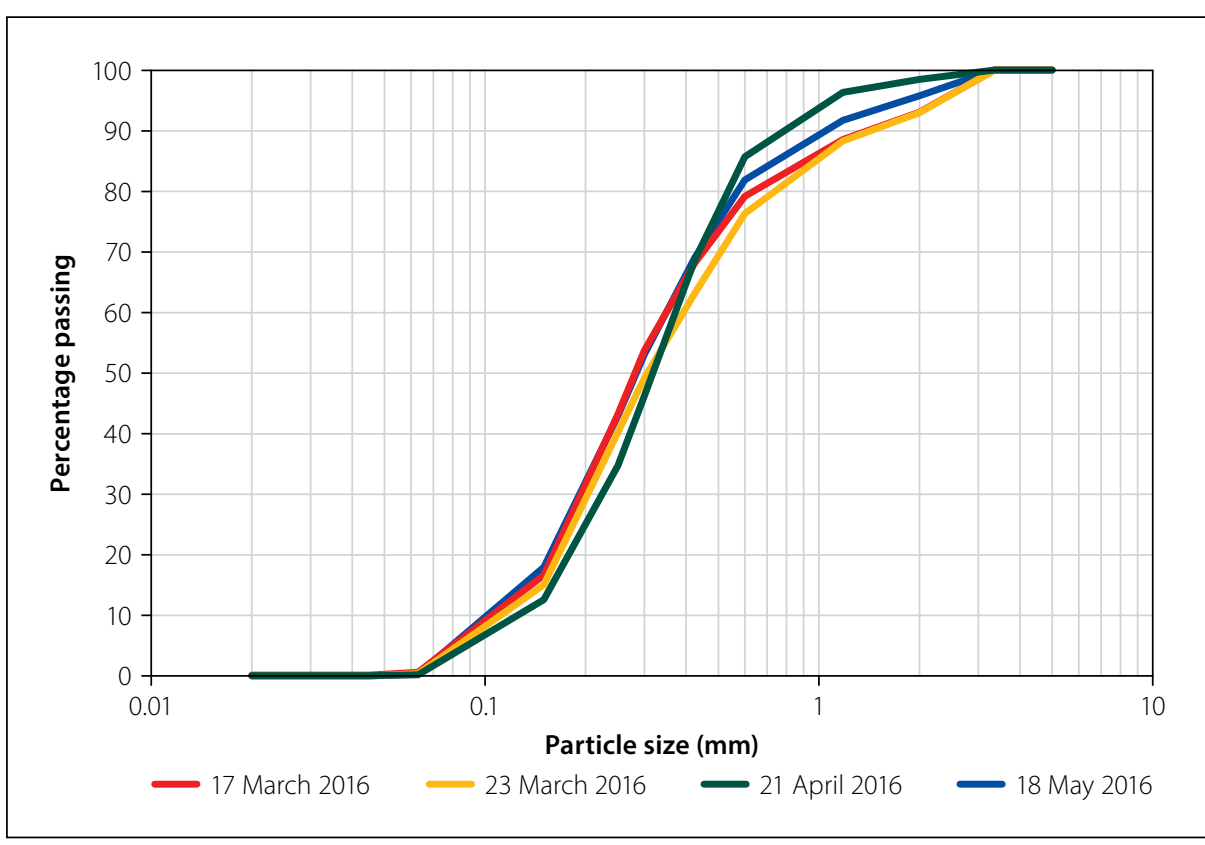

Figure 6 Particle size distribution of sediment on the R300 freeway 
particle size distribution of composite samples taken from the three highway sampling locations for four sampling events. The particle size envelope is small, indicating a relatively homogenous and consistent particle size distribution in the surface sediment on the R300. This has implications for drainage design and controlling sedimentation. Research has shown that a large fraction of the pollutant load is attached to particles, therefore sediment removal is one of the primary means by which to improve surface runoff quality (Woods-Ballard et al 2007).

\section{DISCUSSION AND CONCLUSIONS}

The primary contaminants in the R300 surface water were aluminium, copper, lead, phosphorus, zinc, TSS, and oil and grease. Additionally, large volumes of macro pollutants including cigarettes, plastic and packaging material, were transported by the stormwater system from the highway to the surrounding environment.

The metal contaminant concentration profile is similar in sediment and runoff from the R300 freeway. The results for the surface runoff, however, show a higher level of variability than the sediment samples. Based on this observation, sediment sampling, which is easier and more cost-effective to conduct, can be used to provide an indication of the metal contamination in highway surface runoff.

Based on the magnitude of the solid waste, heavy metal, TSS and oil and grease concentrations in the R300 runoff waters, it is recommended that highway runoff is treated where the water quality may influence a sensitive or valuable aquatic ecosystem. International best management practices and local legislation suggest Sustainable Drainage Systems (SuDS) to ameliorate stormwater runoff quality and assist in controlling solid waste.

The SuDS elements and configuration required to meet performance and site conditions can be determined by modelling the stormwater system using computational decision support software such as PCSWMM (Ahiablame et al 2012). Pollutant modelling can be implemented by specifying an average pollutant concentration in the runoff, which is suitable for long-term modelling where event-to-event errors are not problematic. This approach is widely used, and approximate values are readily attainable in the literature. The mean concentration should, however, be informed by local conditions, as it may otherwise misrepresent the total pollutant loading.
The outcomes of this research indicate that stormwater runoff from urban highways can be a significant source of pollution, and further studies are required to investigate the temporal and spatial variation of pollutant loading across South Africa.

\section{ACKNOWLEDGEMENT}

The authors gratefully acknowledge the South African National Roads Agency Ltd (SANRAL) for their financial support of this project.

\section{REFERENCES}

Ahiablame, L M, Engel, B \& Chaubey, I 2012. Effectiveness of low impact development practices: Literature review and suggestions for future research. Water, Air, and Soil Pollution, 223: 4253-4273.

Anta, J, Peña, E, Suárez, J \& Cagiao, J 2007. A BMP selection process based on the granulometry of runoff solids in a separate urban catchment. Water $S A, 32(3)$. Available at: http://www.hdl.handle. net/10520/EJC116337 [accessed on 13 July 2015].

Armitage, N, Vice, M, Fisher-Jeffes, L, Winter, K, Spiegel, A \& Dunstan, J 2013. The South African Guidelines for Sustainable Drainage Systems. WRC Report TT558/12. Pretoria: Water Research Commission.

Barbosa, A, Fernandes, J \& David, L 2012. Key issues for sustainable urban stormwater management. Water Research, 46(20): 6787-6798.

BS (British Standard) 1990. Methods of Test for Soils for Civil Engineering Purposes. Part 2: Classification Tests. London: British Stanards Institution.

Crabtree, B, Moy, F, Whitehead, M \& Roe, A 2006. Monitoring pollutants in highway runoff. Water and Environment Journal, 20(4): 287-294.

CSRM 2009. Management of urban stormwater impacts policy. City of Cape Town, Roads and Stormwater Department Catchment, Stormwater and River Management (CSRM) Branch. Available at: https://www.capetown.gov.za/en/CSRM/ Pages/Policiesandstrategy.aspx [accessed on 16 February 2016].

DEA (Department of Environmental Affairs) 1984.

General and Special Standards: Requirements for the purification of waste water or effluent. Available at: https://www.dwa.gov.za/Dir_WQM/docs Legis. asp [accessed on 7 May 2015].

Deletic, A 1998. The first flush load of urban surface runoff. Water Research, 32(8): 2462-2470.

Desta, B M, Bruen, M, Higgins, N \& Johnston, P 2007. Highway runoff quality in Ireland. Journal of Environmental Monitoring, 9(4): 366-371.

DWS (Department of Water and Sanitation) 1996. South African Water Quality Guidelines. Volume 7: Aquatic ecosystems. Pretoria: Government Printer. Ellis, J B, Revitt, D M \& Lundy, L 2012. An impact assessment methodology for urban surface runoff quality following best practice treatment. Science of the Total Environment, 416: 172-179.

Field, A 2013. Discovering Statistics using IBM SPSS Statistics, 5th ed. London: SAGE.

Göbel, P, Dierkes, C \& Coldewey, W G 2007. Storm water runoff concentration matrix for urban areas. Journal of Contaminant Hydrology, 91(1-2): 26-42.

Han, Y H, Lau, S L, Kayhanian, M \& Stenstrom,

M K 2006. Correlation analysis among highway stormwater pollutants and characteristics. Water Science and Technology, 53(2): 235-243.

ISO (International Organization for Standardization) 2005. ISO 17025:2005. General Requirements for the Competence of Testing and Calibration Laboratories. Geneva:. ISO.

Kayhanian, M, Suverkropp, C, Ruby, A \& Tsay, K 2007. Characterization and prediction of highway runoff constituent event mean concentration. Journal of Environmental Management, 85(2): 279-295.

Khan, S, Lau, S-L, Kayhanian, M \& Stenstrom, M K 2006. Oil and grease measurement in highway runoff - Sampling time and event mean concentrations. Journal of Environmental Engineering, 132(3): 415-422.

Legret, M \& Pagotto, C 1999. Evaluation of pollutant loadings in the runoff waters from a major rural highway. Science of the Total Environment, 235(1-3): 143-150.

Ma, J-S, Kang, J-H, Kayhanian, M \& Stenstrom, M K 2009. Sampling issues in urban runoff monitoring programs: Composite versus grab. Journal of Environmental Engineering, 135(3): 118-127.

Marsalek, J \& Chocat, B 2002. International report: Stormwater management. Water Science and Technology, 46(6-7): 1-17.

Opher, T \& Friedler, E 2010. Factors affecting highway runoff quality. Urban Water Journal, 7(3): 155-172.

SANRAL 2013. SANRAL Yearbook 2013. Pretoria (Unpublished).

Sartor, J, Boyd, G \& Agardy, F 1974. Water pollution aspects of street surface contaminants. Water Pollution Control Federation, 46(3): 458-467.

Shinya, M, Tsuchinaga, T, Kitano, M, Yamada, Y \& Ishikawa, M 2000. Characterization of heavy metals and polycyclic aromatic hydrocarbons in urban highway runoff. Water Science and Technology, 42(7-8): 201-208.

Vaze, J \& Chiew, F H 2002. Experimental study of pollutant accumulation on an urban road surface. Urban Water, 4(4): 379-389.

Woods-Ballard, B, Kellagher, R, Martin, P, Jefferies, C, Bray, R \& Shaffer, P 2007. The SUDS manual. London: Construction Industry Research and Information Association (CIRIA).

Zafra, C, Temprano, J \& Tejero, I 2011. Distribution of the concentration of heavy metals associated with the sediment particles accumulated on road surfaces. Environmental Technology, 32(9): 997-1008. 